\title{
"The Whole Island is a Jail and We the Warders": States of Exception in Tasmanian Historical Fiction
}

\section{Ellen Turner}

\section{(2) OpenEdition}

1 Journals

Electronic version

URL: https://journals.openedition.org/ces/1076

DOI: $10.4000 /$ ces. 1076

ISSN: 2534-6695

Publisher

SEPC (Société d'études des pays du Commonwealth)

\section{Electronic reference}

Ellen Turner, "'The Whole Island is a Jail and We the Warders": States of Exception in Tasmanian Historical Fiction", Commonwealth Essays and Studies [Online], 42.1 | 2019, Online since 20 December 2019, connection on 23 September 2021. URL: http://journals.openedition.org/ces/1076 ; DOI: https:// doi.org/10.4000/ces. 1076

This text was automatically generated on 23 September 2021.

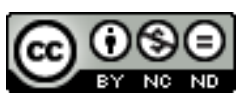

Commonwealth Essays and Studies is licensed under a Licence Creative Commons Attribution - Pas d'Utilisation Commerciale - Pas de Modification 4.0 International. 


\title{
"The Whole Island is a Jail and We the Warders": States of Exception in Tasmanian Historical Fiction
}

\author{
Ellen Turner
}

[T] he past cannot speak for itself - there are only its mute remains and the historian has to attend to them with utmost care. The past cannot defend itself from judgment by the standards of the present. (Macintyre and Clark 2004, 49)

In Exile: A Tale of Old Tasmania (1947), Kathleen Graves writes about Tasmania that "[p]romiscuity leaves its mark - indelible. We are our past, the sum total of us accumulates as we go" (78). The conception of Tasmania as a place whose identity is very much defined by the events of its turbulent past has meant that the island is an ideal setting for historical fiction, with the 1940s being a particularly rich decade for the production of the genre. This article looks at two such fictional works that, in addition to sitting within the broad category of historical romance (in itself a sub-genre of historical fiction), can also be read as exemplars of the gothic romance genre. Writing of the Tasmania of the nineteenth century, Kathleen Graves' Exile (1945) and Isabel Dick's Wild Orchard (1946) construct a history of an island that had altered immeasurably between the early 1800s in which these texts are set and the 1940s in which they were written. Perhaps it is more accurate to say that it was perceptions of the land that had changed. In 1856, to coincide with the colony being granted responsible self-government, the island of Tasmania was officially given its present-day name; the former Van Diemen's Land became a realm belonging to a grisly past. Yet, as the historian James Boyce writes: “Tasmania and Van Diemen's Land are the same place - this was a new name, not a new island - but even today it is easy to forget this" (2008, 1). Through their historical romances, both authors contributed to fabricating the myth of Van Diemen's Land, a Van Diemen's Land that belongs to the realm of fiction. In looking at these authors I aim to enquire into what kinds of histories they are assembling from the fragments of the past. As Diana Wallace notes, "[ $t]$ he very term 
'historical fiction' is a kind of oxymoron, joining 'history' (what is 'true'/'fact') with 'fiction' (what is 'untrue'/'invented,' but may aim at a different kind of truth)" (2005, $\mathrm{x})$. I argue here that, in retelling the story of Tasmania, Dick and Graves are not only recreating a past but also reflecting a present. Here I am indebted to Giorgio Agamben's concept of the state of exception to theorise the supposed threat of savagery, ${ }^{1}$ a threat that undermines legal apparatuses and allows the State to deny basic human rights to the island's inhabitants. Agamben's theory attempts to explain the processes that come into play in times of crisis when normal laws are suspended and certain persons are placed outside of the juridical order. It is just as applicable to an 1840s Van Diemen's Land in which disorder and outlawry ruled as it was to a post-war 1940s world.

2 The history of nineteenth-century Van Diemen's Land is dominated by the image of transported convicts and the events of what has been designated the Black War. Literary representations of what seems to be a land of extremes are dominated by a sense of paradox; on the one hand the island is portrayed as a living hell, and, on the other hand it is seen as a lush and idyllic land, romanticised to the same extent that it is disparaged and vilified. The island was represented, for C.A. Cranston, "as the source of psychic distress, cultural disenfranchisement, intense disappointment, a land scapegoat for social evils, it was gothic, it was grotesque, it was hell, it was heaven, it was penal, it was paradise" $(2003,29)$. Van Diemen's Land was first colonised by the British in the early nineteenth century as a penal colony. For the most part the crimes for which these convicts were transported to Van Diemen's Land were the inevitable upshot of trying to survive in a poverty-ridden nineteenth-century Britain in which the effects of the industrial revolution were being keenly felt.

Running parallel to the story of transportation to nineteenth-century Van Diemen's Land is the narrative of the Black War. Nowhere else in Australia is the history of the conflict between the Aborigine and the European invaders as sinister as in Tasmania. The Black War has dominated Tasmanian history with far more vehemence than similar occurrences taking place in other parts of the colony. Roslynn Haynes accounts for this fact partly on the basis that the war was given a name in Tasmania where it had not in other parts of Australia: "The on-going war between settlers and blacks was waged in all the Australian colonies but because it was given a name in Van Diemen's Land it had lived longer in the national consciousness as a continuing event rather than the separate skirmishes elsewhere" $(2006,79)$. The atrocities perpetrated against the Aborigines in Van Diemen's Land amount to genocide. ${ }^{2}$

James Boyce argues that the tragedy that occurred almost two centuries ago still taints Tasmania's present-day identity. He maintains that "[t]he silence about the government's ethnic clearances - arguably the least defensible official action against an indigenous people committed anywhere in the British empire during the nineteenth century - has been maintained for over 170 years" (2008, 257-58). In public perceptions, the Tasmania of today holds a rather peculiar place. From a European point of view, it is thought of (if indeed it is thought of at all) as a minor appendage to the mainland of Australia. Carmel Bird, who was brought up in 1940s Tasmania, suggests that "[l]ike mud or disease or reputation, the quality of being Tasmanian is tenacious. It is desirable and undesirable at the one time, a sharp mixture of pride, guilt and shame" $(1989,251)$. While Tasmania's profile is steadily being raised and its image being painted in a more favourable light, it nevertheless retains the quality of an outsider (which is, perhaps, part of its appeal). Ken Gelder writes: 
It is, indeed, common in Australian literary studies to speak of the "Tasmanian Gothic," a genre which expresses the sense of Tasmania's peculiar "otherness" in relation to the mainland, as a remote, mysterious and self-enclosed place. In popular parlance, Tasmania is "backward," out of step with civilisation: Transylvania is evoked in a similar way, from the point of view of mainland jurisdiction. $(1994,2)$

5 Tasmania, to this day, is defined in terms of this "otherness" that Gelder identifies, and this is where I want to start my analysis of these two historical novels, Exile and Wild Orchard. Tasmania can in some senses be regarded as an anomaly; geographically isolated and cut-off by its ocean borders, it provides an appealing case-study of a phenomenon that Agamben was later to recognise as a defining paradigm of governance in post-war Europe.

6 Agamben's theory of governance at a time of crisis is based on the notion that power necessitates a dehumanisation of a population. Frequently represented in the novels of Graves and Dick as less than human or animalistic, the convicts are placed in a realm beyond legal protection. The Aborigines too are denied legal status. As Madley writes, "Aborigines were effectively excluded from participation in or protection by the British colonial legal system. The Hobart regime executed both Europeans and Aborigines for killing Europeans but never a European for murdering an Aborigine, despite the fact that Aborigines were frequently shot on sight" $(2008,89)$. Despite proclamations that every inhabitant of Australia should be under Crown protection, ${ }^{3}$ the Aborigines were effectively classed as non-people outside the safeguard of the law on a level that has been considered genocide, which is sometimes read as analogous to the Holocaust.

7 Jesse Shipway writes that, while the Tasmanian genocide may have borne little resemblance to the Holocaust, "the significatory compression that makes all reference to genocide proceed by way of the Shoah brings the two events together" $(2005,215-$ 16). ${ }^{4}$ Our experience of reading Dick's and Graves' fiction now, from our position of privileged detachment, is bound to incorporate an understanding of genocide in part drawn from the Holocaust. While an awareness that these events were by no means synonymous, in addition to the recognition that 1940s Tasmanians would have been mostly unaware of the occurrences of the Holocaust, is important, a reading of these novels through the lens of Holocaust theory might prove effective. Incorporating Agamben's theory of the state of exception, a theory that takes the Nazi concentration camp as its primary exemplar, provides an avenue into reading the political and legal history of Van Diemen's Land. The Van Diemen's Land that is written about in the novels of Dick and Graves is a prison; it can be read as an instance of Agamben's camp as that which not only encompasses the delineated boundaries of the actual prison walls, but also has repercussions throughout society.

Agamben asserts that "In truth, the state of exception is neither external nor internal to the juridical order, and the problem of defining it concerns precisely a threshold, or a zone of indifference, where inside and outside do not exclude each other but rather blur with each other" $(2005,23)$. Agamben's conceptions of the sovereign and the state of exception paradoxically seek to inscribe that which is outside of law within law. The enactment of martial law in Tasmania would be one instance in which the state of exception is enacted, as law is suspended and certain lives (what Agamben designates under the term "bare life") are excluded from legal protection. To be placed in the realm of bare life means that one's life is actively excluded from the political realm and implies the license of the state to infringe on biological life by making illegal actions 
legal through their exclusion from the juridical system. Where I find Agamben's theories most useful in my readings of Dick and Graves is in the universalisability of the condition of the state of exception in which not just the lives of those in the prisons or chain gangs, or those of the Aborigines whose lives are discounted under martial law, but the lives of every single inhabitant of the island become threatened by the way such a system encroaches on personal freedom. While Agamben saw the two World Wars "as a laboratory for testing and honing the functional mechanisms and apparatuses of the state of exception as a paradigm of government" (7), the case of Van Diemen's Land represents an early example of this relegation of people to the category of bare life, albeit an example that, rather than being universalised, is taking place within the clearly defined geographical boundaries of the island.

\section{Isabel Dick and the Myth of Van Diemen's Land}

9 Published in 1946, Isabel Dick's Wild Orchard, though popular in its day, ${ }^{5}$ is now barely mentioned in the history of either Australian or Tasmanian fiction and there is little critical engagement with Dick's work. In their survey of Tasmanian literature, Margaret Giordano and Don Norman, making a rare reference to her fiction, write that "[f]or Isabel Dick, years of struggle as a writer culminated in hitting the bestseller lists in the US with her pioneering novel about Tasmania, Wild Orchard" $(1984,114)$. Dedicated to the early pioneers of Tasmania, Dick's historical romance recounts an apparently conventional tale of love and marriage between hero and heroine Harriat [sic] Bracken and John Halifax (who is Nat to his family and Jan to Harriat). Ostensibly the novel follows a conventional romance plot. The naive and inexperienced girl from a wealthy British family meets and falls in love with the rugged Tasmanian gentleman hops farmer (Halifax) while he is in Kent learning the skills of cultivating the plant so that he might return to Tasmania and raise a successful crop. Frustrated with the confines of polite British society, Harriat is quick to accept a marriage proposal from Halifax and is soon on board a ship to 1840 s Tasmania to start a new life as a married woman. "Transported" from a secure upper-middle class Kent family (far removed from the stratum of British society that made up the convict class), Harriat undergoes a transition, mediated by the long sea voyage, to what is effectively for her another world. Although this new world is for Harriat in part the pastoral idyll of her yearning, it also gradually reveals a darker and more sinister side: events like Maggie, the convict servant, brutally murdering some kittens, the revelation that the place where Harriat and Jan's home is located was the site of a vicious attack on settlers by a group of Aborigines, and Harriat's receiving a visit from a bushranger while she is alone in her house, reflect the island's ominous aspect. Despite the fact that the novel is set almost two decades after the events of the 1820s, its pages are haunted by the island's history. It is difficult to reconcile the sometimes saccharin sweet tone of Dick's novel, characteristic of a number of Tasmanian romances from the era, with the murky other world of old Van Diemen's Land that haunts it.

While not directly alluding to factual events, Wild Orchard is implicitly bound with the past of both Harriat and Dick's ancestors. Dick's novel tells the tales of the hardships and delights of starting a new life in the antipodes. Once in Tasmania Harriat longs for the home she has left behind but eventually reconciles herself to the romanticised Tasmania on which she has a plot of land that she slowly (and at times reluctantly) 
turns into a "little England." This "little England" however is the privileged uppermiddle class England that Harriat belonged to rather than the deprived and workingclass England from which originated the vast majority of the convict population transported to Van Diemen's Land. This notion of Tasmania as a "little England" is one that runs throughout Wild Orchard: "We are as English in our tastes out there as you are here. Don't you realize that we are a Crown Colony, and that we treasure the things of England?" (Dick 1946, 19) And again, Jessie declares:

"If folks at home could realize how we crave to out-British the British! Think how we read and re-read the illustrated papers, think how minutely we watch out for any and every detail of the Royal Family, see how we shape our homes and gardens in the pattern, so far as we are able, of our old homes!" (202)

The Tasmania that Dick seeks to represent alongside the darker, almost gothic Van Diemen's Land is very much the Tasmania of the writer Louisa Meredith, who emigrated there with her husband in 1839, a Tasmania that tries to dispel the myths of the past. ${ }^{6}$ "Little England" can be read as not only the genteel world that Harriat left behind, but also the more miserable existence of those forced to break the law as a matter of survival. This is also the country that induces in Harriat a "horrible feeling of disgust at the sight of the absolute swarms of flies everywhere, even crawling over their food, and where flies didn't crawl, ants did, from tiny black ones that smelt vile when squashed to big 'inch-men,' as they were called, which stung furiously" (Meredith 1979, 135). It is the same country that she at other times sees as a pastoral idyll, as the Bible picture book image of the oxen dragging a plough attests (152).

Dick continually fluctuates between the two Tasmanias, revealing an underlying element of truth in the mythological construction of the island. The "tales of murder and outrage, blacks and bushrangers, in Van Diemen's land" (Dick 1946, 13), which take on the quality of legend back in England, expose their latent, but recent, reality in Tasmania. The life that Harriat's father requests to be told of by his prospective son-inlaw is that of the "savage." As he asks, "Come along, let me know the worst: convicts slayed by cat-o'-nine-tails before shivering crowds, bush-rangers little better than fierce animals who attack defenceless women, animals that sit upright and eat with their front paws daintily as any human" (46). Clearly the little England that Dick both affirms and denies is in part invention. The life to which Jan is taking his wife was one in which "each was obliged to fend for himself - what was more, each must be accountable primarily for his own especial safety" (62). The state of nature then was viewed not just as a property of Aboriginal societies but of invader societies as well. The deprivation and poverty that instigated the arrival of the initial population made up of petty thieves, the general lawlessness that was endemic in a British society with an unjust social system, were transplanted onto this relatively small geographical area. Reflecting a broader paradigm of government, the state of exception that is evident in Tasmania is also somewhat recognisable in British society.

While the treatment of the Aborigines in Dick's novel reflects a layer of concerns not applicable to society in Britain, it does, in a sense, raise the broader issue of what it means to be a human subject, of who benefits from, and who is excluded from, the protection afforded by the legal system. According to a review of Wild Orchard dating from the year of its publication, "[t]he Aborigines are a less important part of the background, but Mrs. Dick recalls their earlier massacres of pioneers and mentions the remorse of some of their persecutors" (Hyder 1946, 203). As Julia Smith writes, "[ $t]$ here are many self-conscious absences in Wild Orchard regarding the darker aspects of 
Tasmania's past" $(2006,13)$. For the most part, the Aborigines are represented as primitive and savage. Harriat, for instance, on reflecting on the settler/invader ideology of terra nullius, thought:

in uninhabited parts of the world [ ... ] such as Van Diemen's Land before the white men came to settle on the Derwent in 1803, there would of course have been the Aborigines making their queer sounds, and there would be birds calling, and the great winds and the wash of the rivers, but in this island there were never any wild beasts to roar, nothing but stealthy sounds of animals padding through undergrowth. (Dick 1946, 111-12)

When the concepts of bare life (the condition of life outside of political protection) and the state of exception contaminate an entire society, they do not remain abstract political theories. Governance under a state of exception encroaches on daily life. As bare life seeps into the domestic sphere, it stands to reason that the cultural products which deal with issues of daily life will absorb, react to, and reflect this new reality. This is why the romance novels of two now obscure women writers can be read according to Agamben's terms. A key feature of the state of exception is the blurring of the public/private divide. As Billie Melman notes of the 1920s "Empire Romance,"

[t]he young Englishwoman, a personification of the old, civilised way of life, may exert a mitigating influence upon her masculine surroundings. More characteristically, she yields to them. Rather than refine the male-inhabited environment and emasculate it, she herself becomes wild, hard and resilient. (YEAR, 140) ${ }^{7}$

This female figure is equally apparent in the novels of Dick and Graves, which can also be described as empire romances, as the female figure moves away from the conventional domestic ideal in a shift that blurs the boundary between domestic and political space. ${ }^{8}$ Agamben claims that when the state of exception becomes universalised, "[b]are life is no longer confined to a particular place or a definite category" and "now dwells in the biological body of every living being" $(1998,140)$. Both Wild Orchard and Exile provide accounts of the functioning of the island in its entirety as a prison. Living from within something resembling the state of nature, all life becomes bare life on the basis of "its capacity to be killed" (Agamben 1998, 8).

Assimilated to wild beasts, the Aborigines are granted a status on a par with the animals. Harriat affirms this sense of inferiority that Europeans conferred upon them when she considers "that less than forty years ago this spot where I sit had never, never vibrated to civilized sounds or English voices..." (Dick 1946, 112). The supposed savagery of the Aborigines is made unambiguous. Telling the tale of brutalities committed against white settlers, a neighbour makes a graphic account of crimes committed by the Aborigines against his own family:

In the yard were my children, speared to death! They lay in one heap. Beyond in the forest where they must have chased her after setting fire to the roof, I found my wife. The natives had attacked her with waddys; she too was dead, my wife, bound to a tree. They, the blacks, those hunted devils, had watched until she was alone, had killed... and had disappeared as silently as snakes. (127)

This man who had once expressed sympathy for the Aborigines articulates his change of heart in response to the above event:

I, who had last year hotly opposed the Black Line, who had argued that by kindness we could win these unhappy creatures whose country the white race had filched, for whose cause I had made endless appeal, written endless articles begging patience with their ignorance, had given to them from my small means, only to be repaid by this foul treachery. (127) 
He continues even more vehemently: "[t]heir black hearts can distinguish no good in any man with a white skin. I suffer for the atrocities practised on the native race by convicted felons, by bushrangers who are themselves but escaped convicts, yes, and by settlers too" (127). However, despite this racist sentiment, at times the past treatment of the Aborigines is dealt with slightly more sensitively. For instance, we are told that Appleby "can never forgive himself for being one of the prime movers in the "Black Line"' (173). Despite Dick's intention to convey the events of the 1820s in a factual light, the Aborigines are nevertheless depicted as inferior beings to be "fixed" by the "civilised" settler race: "We should have invited those poor blacks to share our firesides, encouraged them to dress as we do, eat as we do. Cured them of their savage ways by kindness" (185).

On hearing that the land on which she and her husband had built a home and a life "was the scene of a terrible outrage," Harriat reflects on the fact "that in this smiling country deadly monstrous happenings lurked below so thin a crust!" (Dick 1946, 267) Harriat is told that the "[b]lacks, whites, and bushrangers militated against each other with equal violence" (206), but there is still a part of her that condones such outlawed violence. For instance, after the incident in which she finds herself in her house, alone, with an infamous bushranger, she sees him as a hero rather than a villain: "No, she would not breathe a word of it. So she hid away the copy of the Times. And long afterwards the signature of Martin Cash and the scribbled message above it became a cherished family heirloom" (276). Martin Cash, like Ned Kelly, was a notorious bushranger whose legend has grown into an almost mythical status. ${ }^{9}$ In this instance the anarchy of the bush enters a domestic sphere whose boundaries have become permeable to the disorder and seeming lawlessness of the world outside its walls. There is an equivalent scene in Kathleen Graves' Exile. On hearing the story of O'Dowd the bushranger, Richard "had a sneaking feeling of admiration for the outlaw, not with the troops and field police hot on his tail. Even the settlers themselves hated the police, who had all been convicts in the gangs in the first place, but as hard workers had been raised to the position of spies" (61). What both these instances reveal is a respect for the outlaw and the system of self-preservation made necessary when law fails to fulfil its function.

This conflation of the public and the private is a theme that is central to a reading of these texts in terms of a theory of the state of exception. Jerome de Groot argues that "[h]istory is other, and the present familiar. [...] The historical novelist [...] explores the dissonance and displacement between then and now, making the past recognisable but simultaneously authentically unfamiliar" $(2010,3)$. Both Exile and Wild Orchard operate within this complex relationship to the past, existing as they do within the very familiar conservative and domestic space of the historical romance and simultaneously disrupting this with the spectre of the gothic; hence we are reading both the familiar and the uncanny. Sigmund Freud in "The Uncanny" spoke of the linguistic intricacies of the German term das Unheimliche (the uncanny) in relation to its peculiar conflation with its opposite: "The uncanny (das Unheimliche, 'the unhomely') is in some way a species of the familiar (das Heimliche, 'the homely')" (2003, 134). As Julia Kristeva describes this phenomenon, "in the very word heimlich, the familiar and intimate are reversed into their opposites, brought together with the contrary meaning of 'uncanny strangeness' harboured in unheimlich" $(1991,182)$. Kristeva goes on to analyse the uncanny in terms of its temporality, arguing that "that which is strangely uncanny 
would be that which was (the past tense is important) familiar and, under certain conditions (which ones?), emerges" (183). The past that is represented in the novels under consideration here is one that is uncanny by virtue of this phenomenon; that which was once familiar is made strange because of its temporal distance from the subject - a sense of the uncanny that is exacerbated for the present-day reader by virtue of its double layer of "pastness."

\section{Writing the state of exception in Kathleen Graves' Exile: A Tale of Old Tasmania}

17 The gothic is a term that seems to loom over any reference to Tasmanian history or literature. Graves and Dick write within the gothic romance genre in that "they see history not as a source of information or something to understand but as a place of horror and savagery. [...] [N]ot a repository of pastness but a site where history might attack the visitor" (de Groot 2010, 15). The threat perceived in early nineteenthcentury Van Diemen's Land finds an altered but equally visible presence in 1940s Tasmania. In 1947, one year after Dick's Wild Orchard, Kathleen Graves' historical novel Exile: A Tale of Old Tasmania was published. Set in 1826, two years before martial law was declared against the Aborigines, Exile tells the story of Richard Thursby's arrival from England, and his subsequent settlement in Tasmania. The novel commences: "It was on the morning of January the $29^{\text {th }}$, when the ship, Andromeda, was a hundred and sixtytwo days out from Gravesend, that a low cloud appeared on the horizon right ahead" (Graves 1947, 10). As in Wild Orchard, the Aborigines represented in Graves' novel are dehumanised figures used to set-off the exotic staging. They are described by the captain of the ship in which Thursby sails as "[n]asty dangerous varmints" (13). They are depicted as "dirty, lazy wretches, given to hunting and idleness, and are nothing but a plague to the settlers" (14). However, we are told that "[f]or Richard Thursby the fires of the natives added one more touch of mysterious savages to the unknown land" (14). Unlike Wild Orchard, which constantly shifts between the heaven and hell of the two Tasmanias, the fictional realm of Exile lies within a kind of purgatory. Richard goes to Tasmania full of hope, only to become disillusioned. He marries, but his wife falls in love with another man. Many of his sheep perish, and his convict servants are taken away from him. While the setting is certainly far from the pastoral idyll that Dick describes in Wild Orchard, it is not irredeemably unhappy either. Ultimately husband and wife discover a renewed love for one another, the disease in the sheep disappears and Richard is allocated servants once again to help him on his farm.

As Graves writes in her 1953 non-fictional account of life in Tasmania, Tasmanian Pastoral, "it may be the abysmal loneliness of the bush, as well as the mountains, which nurtures that lack of spirituality and the underlying melancholy tinged with irony which is expressed in our literature" (128). The Tasmania of Exile is characterised by a similar tone that hints at a degree of resignation to a satisfactory, if harsh existence. Graves' book also lends a certain credibility to her earlier novel by confirming the version of history that it reflected. ${ }^{10}$ However, rather than describing Tasmanian history as something atrocious, as it is represented in Exile, Tasmanian Pastoral reads the history of the island as something congruent with a future good life for the island's settlers. According to Graves, her Tasmania "has seen the black man with his spear depart, and the white man bring his sickle and his bullock team, then his horse-plough, 
and now the tractors that hasten to and fro across the plain" $(1953,136)$. A rendering of history such as this denies the traumatic nature of the island's past. In this sense, Exile is a "tale of old Tasmania" rather than a tale of Van Diemen's Land. Graves speaks of a Tasmania contiguous with a 1940s or 1950s Tasmania and as such seeks to assuage guilt and render past deeds bearable to present inhabitants.

Dick's Wild Orchard views the savagery of Tasmania as both its curse and its redeeming feature; Graves' Tasmania in Exile is characterised by a sense of lawlessness that requires the whole island to function as a prison. Although Tasmania at this time was known primarily as a penal colony, the metaphor of incarceration and the penal system is extended to encompass the whole of the supposedly free population of the island as well. As Richard's escort on first arriving in Tasmania tells him:

If you settle here, as I assume you intend, you will find your lot little better than that of a convict warder. Where he fears the lash and the chain-gang, you will fear the withdrawal of servants, the refusal of an extension of grant, the calling up of quit-rents, the fresh survey of boundaries, even inquiries into the validity of titledeeds. It all depends on your behaviour. The whole island is a jail and we the warders. (Graves 1947, 25)

20 In Exile Richard too is drawn in by the mystery of the island but is equally oppressed by it. It is in some senses a life sentence for him: "there might be no going back" (Graves 1947, 27). As Graves writes of the Tasmanian mountains and bush, "[t]here was something about it which was frightening: it represented the force of natural power that man had always feared, and it hid the wild animals and wild men securely" (7879). There is a sense that the prison that is Van Diemen's Land is something that runs deeper than a man-made prison, as if it were underlain by a natural power beyond that of the human. By placing this prison-like nature of the island in a realm that precedes human influence, Graves is perhaps attempting to avoid attributing any sense of blame, suggesting that there is something intrinsically connected with the island which enthrals its inhabitants. The island captivates Richard so that he is bound to it in terms similar to an incarceration: "The island had begun to cast a spell over him, a spell from which he was never to be free for the rest of his days" (42). The mountains and the bush represent a kind of lawlessness that is reflected in the ungovernability of the island's inhabitants. Likewise, his wife Clair both despises and is in awe of the view of the mountains. Speaking to Clair, his friend's wife and the woman he loves, Kinnaird says "I love it and hate it myself. The prison walls!" (127).

21 To Richard, on his arrival, Tasmania represents "an irregular state of affairs - outlaws' strongholds, bribed police, murdering blacks, and whatnots" (Graves 1947, 37). It is an island governed by an intended disciplinarian system under which all of society operated: "Here it was, disciplined to a curfew, and brooding over all a figure almost sinister, the tall man who had come aboard the Andromeda that morning" (27). The suggestion is that the inhabitants of the island would be ungovernable by any other means. Graves' Governor proposed to "take matters into his own hands as he always had done, parcel out grants double the size, defy the Secretary of State, the Parliamentary Committee and their ideas as if they never existed" (208). He sees himself as the supreme authority, the absolute sovereign: "No one could set him limits, he who had the power of life and death in his own hands" (208). As the Governor understands it, "the only way to govern a convict colony was to control all the people in it" (207, emphasis in original). The whole island is subsumed under a very distinctive form of governance in which legality is decided not by the letter of the law but rather 
by the word of this figure of the despot. In this seeming state of nature, human life subsists outside of the protection of law. According to Agamben, sovereignty is defined by the capacity to decide on the exception when what the exception amounts to is the suspension of law; in Agamben's terms, "a suspension of the juridical order itself" $(2005,4) \cdot{ }^{11}$

In the state of exception all life becomes, for Agamben, bare life. In the state of exception anyone excluded by the sovereign from the political realm can be killed with impunity. Agamben sees the origins of the universalised state of exception in the emergency measures employed by states in the First World War, but declaration of martial law in Tasmania in 1828, which effectively legitimated the murder of Aborigines, can be regarded as an earlier, more isolated instance of this phenomenon. There might however be an argument for suggesting that Tasmania represents a microscale state of exception, which encompasses not only the Aborigines but the whole of society, European settlers included. As Graves has one of her characters say, "[i]t appears that the colony is regarded as nothing more than a jail, the inhabitants no better than pickpockets, murderers and convicted felons of all degrees. Apparently there is no idea of a free population" (1947, 111-12). All are subsumed under the category of bare life.

The notion of bare life, of being placed outside the protection of the law, is nowhere more apparent than in the treatment of the Aborigines. The Aborigines in Graves' novel are not given any voice but are rather treated as specimens to be observed. In line with 1820s perceptions of the indigenous people, Graves represents a view of the Aborigine as not quite human. Kinnaird, for instance, imagines the Aborigine "crouched in lairs like the beasts. [...] He was also an exile, as they all were in this pre-human land" (1947, 124). Graves' Aborigines are described in almost animalistic terms: "a black lass can drop a bairn as easy as ewes their lambs" (152), and similarly: "I wonder why we have this feeling of repulsion for the black man. Eumarrah in his own way is a good fellow, and yet one can never forget his colour. They are so like us, and yet unlike - as in a grotesque way animals resemble us" (179). When a group of settlers fire upon the Aborigines, in the process killing a number of them, Richard ponders how "[t]he whole business was little short of murder" (168-69). The killings were "short of murder" and not, according to Richard's interpretation of events, actual murder. While the more explicit rendering of the concept of bare life is limited to the Aborigine and the convict on the island, the general sense of the precariousness of life is unmitigated as it affects all human beings on the island.

Reading the narrative histories of Graves and Dick, we are reminded of events occurring after the settlement/invasion of Van Diemen's Land. Their words contain echoes of the colonial project from the past and the ongoing problem of racism towards Aborigines in Australia. Graves and Dick, though writers of fiction, are also writers of history and, as John Arnold writes, "historians do not uncover the story of the past, they produce it (and all its meanings, whether explicit or implicit)" (2007, 121). Any writing of history, whether it claims to be objective or fictional, is necessarily affected by the present. In writing this past, the history of a Tasmania inhabited by animal-like natives and equally brutish and bestial convicts and bushmen, Graves and Dick are also speaking of their tainted present. When Graves writes of the uncanny experience of "[p]recognition - that state of being aware at a first meeting that the person is no stranger, that one has known him or her before, and upon visiting an entirely new 
scene that one has seen it before," she describes it as "one of those supernormal things that happen to most people. Perhaps it is in dreams, those weird excursions into the future, that we have visited these places, have met these people" $(1947,116)$. The events of the novel are themselves echoes of the past, views of the present, and potentially predictions of the future, a merging of these temporal dimensions into one space.

In the introduction to Clive Turnbull's history of Tasmania, Black War (1948), H. Ian Hogbin writes that the "aboriginal problem" was still a major concern in 1940s Australia. As he writes:

The worst brutalities of Hobart Town are perhaps unlikely to be repeated today, but anyone who has had contact with our own natives, either around our country towns or in the central and western deserts, will agree that there is no cause for us to congratulate ourselves on what we are doing for them. The reserve, advocated by many - naturally, in a country which no cattle station requires - would only create the same sort of human zoo as that in which the last Tasmanians died on Flinders Island. (II-III)

The image of the "human zoo" that Hogbin sees as threatening Australia is a particularly vivid image of the possible culmination of the state of exception. Although, in theory, all Aborigines were British subjects entitled to the legal protection this status should have afforded them, in practice treatment of Aborigines was far from equal. As Macintyre and Clark write, "Indigenous people were written out of Australian history following the establishment of the nation-state at the end of the nineteenth century. The new Commonwealth sought racial purity. It deprived Aborigines of voting rights, excluded them from the body politic and joined with the states to confine them on reserves" $(2004,43)$. The state of exception that encompasses Dick's and Graves' nineteenth-century Tasmania is also a real threat to their contemporary society. In considering the two novels as part of a layering of narratives that retells the past, it is important to recognise that they are also inextricably bound up with the 1940s perceptions of life in Tasmania. Jesse Shipway describes the state of affairs in the early years of European settlement in Tasmania as "decidedly pre-modern." Correspondingly, the idea of democracy is described as "non-existent." As Shipway goes on to write: "It was a prison, a place to forget" $(2005,218)$. In narrating their past, it seems that Dick and Graves are both attempting to situate this narrative firmly in history, in a place from which it cannot contaminate the present, and indeed, the future of their island. In actuality though, we can see, looking back at Van Diemen's Land, a past form of governance that has become, in Agamben's terms, a paradigm of power in modern Western society. For Carmel Bird, "[t]he repression of these memories has had the effect of filling the island with ghosts. [...] Tasmania is a haunted place" $(1989,252)$. Perhaps, by recognising these memories and affording them the attention they deserve, we are in some small part exorcising this ghost. 


\section{BIBLIOGRAPHY}

AGAMBEN, Giorgio. 1998. Homo Sacer: Sovereign Power and Bare Life. Translated by Daniel HellerRoazen. Stanford: Stanford University Press.

AGAMBEN, Giorgio. 2005. The State of Exception. Translated by Kevin Attell. Chicago: University of Chicago Press.

ARNOLD, John H. 2007. "Responses to the Postmodern Challenge; Or, what Might History Become?" European History Quarterly 37, no. 1: 109-32.

BIRD, Carmel. 1989. "Some of the Ghosts: Growing Up in Tasmania." Australian Literary Studies 14, no. 2: 251-53.

BOYCE, James. 2008. Van Diemen's Land. Melbourne: Black Inc.

CRANSTON, C.A. 2003. "Rambling in Overdrive: Travelling Through Tasmanian Literature." Tasmanian Historical Studies 8, no. 2: 28-39.

COAD, David. 2002. Gender Trouble Down Under: Australian Masculinities. Valenciennes: Presses Universitaires de Valenciennes.

DE GROOT, Jerome. 2010. The Historical Novel. Abingdon: Routledge.

DICK, Isabel. 1946. Wild Orchard. London: Harrap.

"The early days of Tasmania are depicted in the book Wild Orchard." 1946, 11 April. Western Mail (Perth, WA: 1885-1954): 33. https://trove.nla.gov.au/newspaper/article/38574411.

FREUD, Sigmund. 2003. The Uncanny. Translated by David McLintock. London: Penguin. Originally published as Das Unheimliche (1919).

GELDER, Ken. 1994. Reading the Vampire. London: Routledge.

GELDER, Ken, and Jane M. JACOBS. 1998. Uncanny Australia: Sacredness and Identity in a Postcolonial Nation. Melbourne: Melbourne University Press.

GIORDANO, Margaret, and Don NORMAN. 1984. Tasmanian Literary Landmarks. Lenah Valley: Shearwater Press.

GRAVES, Kathleen E. 1947. Exile: A Tale of Old Tasmania. Bournemouth: William Earl.

GRAVES, Kathleen E. 1953. Tasmanian Pastoral. Carlton, Victoria: Melbourne University Press.

HAYNES, Roslynn D. 2006. Tasmanian Visions: Landscapes in Writing, Art and Photography. Sandy Bay, Tasmania: Polymath Press.

HOGBIN, H. Ian. 1948. "Introduction." In Black War: The Extermination of the Tasmanian Aborigines, edited by Clive Turnbull, I-III. Melbourne: F.W. Cheshire.

HYDER, Clyde K. 1946. "Review of Isabel Dick's Wild Orchard.” The Journal of American Folklore 59, no. 232: 203-4.

KRISTEVA, Julia. 1991. Strangers to Ourselves. Translated by Leon S. Roudiez. New York: Columbia University Press.

“Latest Fiction." 1946, 11 May. The Advertiser (Adelaide, SA: 1931-1954): 4. https://trove.nla.gov.au/ newspaper/article/35694140. 
MADLEY, Benjamin. 2008. “From Terror to Genocide: Britain's Tasmanian Penal Colony and Australia's History Wars.” Journal of British Studies 47: 77-106.

MACINTYRE, Stuart, and Anna CLARK. 2004. The History Wars. Melbourne: Melbourne University Press.

MELMAN, Billie. 1988. Women and the Popular Imagination in the Twenties: Flappers and Nymphs. Basingstoke: Macmillan. MEREDITH, Louisa. 1979. My Home in Tasmania. Adelaide: Sullivan's Cove.

"Romantic Tale of Early Tasmania." 1946, 22 April. The Telegraph (Brisbane, Qld.: 1872-1947): 2. https://trove.nla.gov.au/newspaper/article/201331108.

SHIPWAY, Jesse. 2005. "Modern by Analogy: Modernity, Shoah and the Tasmanian Genocide."

Journal of Genocide Research 7, no. 2: 205-19.

SMITH, Julia. 2006. "There She Lay Uncovered: Women and the Land in the Novels of Isabel Dick." Diss., University of Tasmania.

“Tasmanian Setting for AR Serial." 1950, 26 October. The Age (Melbourne, Vic.: 1854 - 1954): 1 (The Age Radio Supplement). https://trove.nla.gov.au/newspaper/article/205374801

TEO, Hsu-Ming. 2016. "Imperial Affairs: The British Empire and the Romantic Novel, 1890-1939." In New Directions in Popular Fiction, 87-110. London: Palgrave Macmillan.

TURNBULL, Clive. 1948. Black War: The Extermination of the Tasmanian Aborigines. Melbourne: F.W. Cheshire.

WALLACE, Diana. 2005. The Women's Historical Novel. Basingstoke: Palgrave Macmillan.

WOLFE, Patrick. 2006. "Settler Colonialism and the Elimination of the Native." Journal of Genocide Research 8, no. 4: 387-409.

\section{NOTES}

1. Here the term is used in the OED's sense of "the condition of being primitive and uncivilized; a primitive state of human society" ("savagery, n.").

2. Benjamin Madley concludes that "Tasmania under British rule was clearly a site of genocide" $(2008,106)$.

3. Clive Turnbull quotes the report of the 1837 Select Committee on Aborigines: "If the whole of New Holland be part of the British Empire, then every inhabitant of that vast island is under the defense of British law as often as his life or property may be attacked, and the appeal to arms for adjusting controversies with any part of the primitive race, exposes those by whom blood may be shed to the same responsibility, and to the same penalties, as if the sufferers were white persons" (1948, 241).

4. The issue is further explored by Patrick Wolfe who theorises the "relationship between genocide and the settler-colonial tendency that [Wolfe] term[s] the logic of elimination" (2006, 387).

5. Examples of contemporary reviews include those featuring in the 11 April 1946 edition of the Western Mail ("The early days of Tasmania are depicted in the book Wild Orchard," 33), the 11 May 1946 edition of The Advertiser ("Latest Fiction," 4), and 22 April 1946 edition of The Telegraph ("Romantic Tale of Early Tasmania," 2). Confirmation of the claim that the novel was popular in 
its day can be found in an announcement in The Age Radio Supplement in October 1950 that the novel is to be serialised for radio broadcast ("Tasmanian Setting for AR Serial," 1).

6. Meredith writes: "No general descriptions would so well tend to show the truth, as the veritable chronicle of everyday life [...], as innocent of lawless intrusions as dwellings of a like isolated and lonely character would be in any part of Britain" (1979, XV-XVI).

7. For further discussion on the genre of the Empire Romance see Hsu-Ming Teo's "Imperial Affairs: The British Empire and the Romantic Novel, 1890-1939" (2016).

8. As David Coad writes: "The idea of female masculinity appeared in both fictional and nonfictional writing in the second half of the nineteenth century and is still a visible feature of contemporary Australian society. The protagonist of Henry Lawson's short story 'The Drover's Wife,' first published in 1892, has become a literary myth in Australia and encapsulates the idea of female masculinity from the outback" $(2002,99)$.

9. David Coad writes of the Australian bushranger that "[j] ust as the American West has its cowboy heroes, Australia fondly remembers a certain number of Outback criminals known for their daring, audacity and robbery under arms. [...] The bushranging spirit is synonymous with an anti-Establishment desire" $(2002,46)$.

10. In Tasmanian Pastoral Graves writes of the bush-ranging gangs as well as the Black Line and the Black War.

11. The term sovereignty employed in this sense is, of course, different from Aboriginal sovereignty, a complex term that refers to the recognition of Aboriginal customs and laws, and the right to self-governance.

\section{ABSTRACTS}

Looking at two historical romances by women writers, Kathleen Graves' Exile: A Tale of Old Tasmania (1945) and Isabel Dick's Wild Orchard (1946), this article seeks to examine narratives of an early nineteenth-century Van Diemen's Land that are apparently at odds with the 1940s Tasmania it was to become. Drawing on Giorgio Agamben's "state of exception" as the theoretical underpinnings for this essay, I read both the nineteenth- and twentieth-century island as a site for the proliferation of bare life whereby the whole of society finds itself defined by its prisonlike capacity to strip individuals of their right to life. In telling these stories in which not all lives are equal, it seems that Dick and Graves are attempting to situate their narratives firmly in the past where they cannot contaminate the present, and indeed, future of their island.

INDEX

Keywords: Agamben (Giorgio), Tasmanian literature, Van Diemen's Land, state of exception, historical romance 


\section{AUTHOR}

\section{ELLEN TURNER}

Lund University

Ellen Turner is a senior lecturer in English Literature at Lund University. Her Ph.D. thesis on conceptions of sovereignty and domesticity in interwar women's writing explored the relationship between popular low- or middlebrow writing and modernist fiction. She has published articles on detective fiction and physical cultures as well as E.M. Hull and the desert romance genre. 